\title{
Phenotypic and Seed Protein Analysis in 31 Lima Bean (Phaseolus lunatus) Accessions in Ghana
}

\author{
I. K. Asante ${ }^{1 *}$, S. K. Offei², R. Addy ${ }^{3}$, A. G. Carson ${ }^{3}$ \\ ${ }^{1}$ Department of Botany, University of Ghana, P. O. Box LG55, Legon, Ghana \\ ${ }^{2}$ Department of Crop Science, University of Ghana, P. O. Box 44, Legon, Ghana \\ ${ }^{3}$ Department of Crop Science, University of Cape Coast, Cape Coast, Ghana \\ *Corresponding author
}

\begin{abstract}
Phenotypic and seed protein analyses were performed on 31 accessions of Lima bean assembled in Ghana. Data on 16 phenotypic characters consisting of eight quantitative and eight qualitative were analysed. There were significant differences among the accessions based on the eight quantitative characters. Seed protein analysis showed 17 bands with relative mobility of bands, which ranged from 0.01 to 0.86 . An ordinal logistic regression analysis showed significant evidence for seed coat, pod beak shape and seed size association. Cluster analysis based on both phenotypic and protein data provided evidence for differences among the accessions. Quantitative characters were associated with some specific clusters.
\end{abstract}

\section{Introduction}

Lima bean (Phaseolus lunatus L.) is the most important food legume within the neotropical genus Phaseolus (Baudoin et al., 1991). In Ghana it is fourth in importance after cowpea, groundnut and bambara groundnut (Doku, 1977) while in Nigeria, it is placed second in importance to cowpea (FAO/CCTA, 1958). In tropical Africa the crop is interplanted with crops such as maize, sorghum, sweet potatoe, coffee, cotton and yam. The crop is hardy and may be advantageous in adverse conditions where other leguminous vegetables do not grow well (FAO, 1984).

The banding patterns produced by seed protein electrophoresis have been used to effectively characterize cultivars of pasture grasses and legumes (Sheidai et al., 2000), Capsicum annuum and $C$. frutescens (Odeigah et al., 1993). Multiple domestication centres have been suggested through the seed protein electrophoresis analysis from different wild and cultivated accessions of common bean (Gepts et al., 1986). Seed storage protein electrophoresis has been used to estimate diversity among accessions in genetic resources collection and species inter-relationships (Gardiner \& Forbe, 1992; Badr, 1995). Generally, seed storage proteins have been used as markers in the following four main areas: analysis of genetic diversity within and among populations, plant domestication in relation to genetic resources conservation and breeding, genome relationships especially in polyploid series, and as a tool in plant breeding (Gepts, 1990).

Storage seed protein satisfies the requirements of genetic markers for the following reasons: they are highly polymorphic, their polymorphism is genetically determined and the molecular sources of their polymorphism are known; their control of qualitative genetic variations is simple and involves limited number of loci of nuclear genome; and they show that most protein variants are unique and can, therefore, be used as evolutionary markers. Finally, homologies have been established between seed storage proteins of different taxa (Gepts, 1990). The objective of the study was to use seed protein and phenotypic analyses to study variety inter-relationships and provide data on differences among accessions of $P$. lunatus in Ghana.

\section{Materials and methods}

Morphometry

The 31 accessions of Lima bean used for the experiment were collections from local farmers and market places. They form the total number of Lima bean collections at the Plant Genetic Resources Centre of Ghana at Bunso in the Eastern Region. The accessions were as follows:

West African Journal of Applied Ecology, Vol. 12, 2008 
99/001, 99/002, 99/003, 99/004, 99/005, 99/006, 99/007, 99/008, 82/293, 82/292, 99/009, 99/010, 99/011, 99/012, 82/414, 82/125, 87/160, 87/134, 82/166, 87/118, 99/013, 82/482, 82/493, 82/469, 82/489, 99/014, 99/015, 99/017, 99/018, 82/496 and 82/505.

The experiment was conducted in 2003 in the University of Ghana Research Farms of the Department of Crop Science. The accessions were planted in a completely randomized design (CRD) with three replications. Each entry had two rows per replication and each row was $5.0 \mathrm{~m}$ long. The rows were $50 \mathrm{~cm}$ apart and plants within a row were $30 \mathrm{~cm}$ apart. Two seeds were planted per hill and thinned out to one plant per hill at 10 days after seedling emergence. There was no fertilizer application. The morphological characters studied were grain yield, number of seeds per pod, 100-seed weight, seed width, seed length, cyanide content (mg/100 g), pod beak shape, flower wing colour, keel colour, pod hairiness, wing opening position, pod dehiscence, raceme position, leaf persistence, terminal leaflet length and seed coat colour. These characters were selected on the basis that they are among the standard characters in the Lima Descriptor by the Plant Genetic Resources Institute.

\section{Protein extraction and electrophoresis}

Protein electrophoresis by SDS-PAGE was performed according to modified method of Sanchez-Yelamo et al. (1995), using $0.39 M$ tris phosphate buffer $(p \mathrm{H} \mathrm{6.8)}$ for extraction. The crude extracts were boiled for $2 \mathrm{~min}$. in tris $0.0625 \mathrm{M}$ tris/ $\mathrm{HCl}(p \mathrm{H} 6.8), 2 \%$ sodium dodecyl sulphate (SDS), \%\% 2-mercaptoethanol and 10\% glycerol. The gels were loaded with $15 \mu \mathrm{l}$ of the seed protein extracts and were electrophoresed at a constant $30 \mathrm{~mA}$ for $8 \mathrm{~h}$. Coomassie Brilliant Blue G-250 was used for staining the gel and stored in $20 \%$ glycerol solution.

\section{Data analysis}

Gowers similarity coefficient was used to estimate similarity of accessions based on the phenotypic traits morphological characters. The Jaccard's index was used to estimate similarity among the accessions as indicated by protein electrophoresis patterns. All similarity coefficients were based on the UPGMA by using the SPSS package. The ordinal logistic regression analysis was performed by using Minitab Software package to test for association between quantitative and qualitative traits.

\section{Phenotypic characters}

A summary of variability of the eight quantitative characters is presented in Table 1 . There were significant differences among the accessions for all the eight quantitative characters as indicated by the standard error of difference. Number of pods per plant ranged from 40.34 to 87.00 with a mean of 56.86. The 100 -seed weight ranged from 23.84 to $71.81 \mathrm{~g}$ with a mean of $50.84 \mathrm{~g}$. Grain yield per plant ranged from 31.73 to $144.40 \mathrm{~g}$ with a mean of $83.86 \mathrm{~g}$. Cyanide content ranged from 5.20 to $7.18 \mathrm{mg} / 100 \mathrm{~g}$ with a mean of $6.15 \mathrm{mg} / 100 \mathrm{~g}$. Seed width ranged from 0.62 to $1.25 \mathrm{~cm}$ with a mean of $0.99 \mathrm{~cm}$. Seed length ranged from 0.86 to $1.77 \mathrm{~cm}$ with a mean of $1.45 \mathrm{~cm}$. Terminal leaflet width and length ranged from 2.44 to $7.59 \mathrm{~cm}$ and 6.47 to $10.58 \mathrm{~cm}$, with means of $5.97 \mathrm{~cm}$ and $7.79 \mathrm{~cm}$, respectively. Table 2 shows a summary of the qualitative characters studied. Four seed coat colour patterns were observed among the 31 accessions. Three different classes were observed for each of pod beak shape, flower wing colour and pod raceme position. Two different classes were observed for each of flower keel colour, hairiness of standard petal, nature of wing opening and pod dehiscence.

TABLE 1

Quantitative characters of 31 Lima bean accessions

West African Journal of Applied Ecology, Vol. 12, 2008 


\begin{tabular}{|c|c|c|c|c|c|c|c|c|}
\hline Accessions & $\begin{array}{l}\text { Number of } \\
\text { pods per } \\
\text { plant }\end{array}$ & $\begin{array}{c}\text { 100-seed } \\
\text { weight } \\
(\mathrm{g})\end{array}$ & $\begin{array}{c}\text { Grain } \\
\text { yield per } \\
\text { plant }(\mathrm{g})\end{array}$ & $\begin{array}{l}\text { Seed } \\
\text { width } \\
(\mathrm{cm})\end{array}$ & $\begin{array}{c}\text { Seed } \\
\text { length } \\
(\mathrm{cm})\end{array}$ & $\begin{array}{c}H C N \\
(m g / 100 g)\end{array}$ & $\begin{array}{c}\text { Terminal } \\
\text { leaflet width } \\
(\mathrm{cm})\end{array}$ & $\begin{array}{c}\text { Terminal } \\
\text { leaflet length } \\
(\mathrm{cm})\end{array}$ \\
\hline 99/001 & 65.03 & 63.50 & 124.00 & 1.16 & 1.75 & 5.80 & 6.01 & 7.85 \\
\hline 99/002 & 62.47 & 41.12 & 73.69 & 0.96 & 1.40 & 7.80 & 7.59 & 8.51 \\
\hline 99/003 & 44.07 & 23.84 & 31.73 & 0.62 & 0.86 & 7.10 & 4.94 & 6.78 \\
\hline 99/004 & 64.33 & 38.96 & 69.61 & 0.95 & 1.30 & 6.10 & 6.90 & 10.09 \\
\hline $99 / 005$ & 53.14 & 61.25 & 96.69 & 1.12 & 1.69 & 6.25 & 6.20 & 7.95 \\
\hline 99/006 & 59.27 & 65.53 & 108.40 & 1.25 & 1.88 & 5.50 & 7.19 & 9.18 \\
\hline 99/007 & 54.00 & 27.39 & 44.58 & 0.70 & 0.98 & 5.35 & 4.59 & 7.69 \\
\hline 99/008 & 69.60 & 32.37 & 63.51 & 0.89 & 1.08 & 5.20 & 5.23 & 7.67 \\
\hline $82 / 293$ & 60.73 & 70.36 & 122.80 & 1.21 & 1.77 & 5.60 & 7.19 & 8.81 \\
\hline $82 / 292$ & 87.80 & 25.06 & 64.06 & 0.74 & 0.90 & 5.50 & 5.53 & 7.85 \\
\hline 99/009 & 57.27 & 29.45 & 49.57 & 0.74 & 0.97 & 7.85 & 2.44 & 10.58 \\
\hline 99/010 & 44.80 & 67.72 & 92.33 & 0.95 & 1.53 & 6.25 & 6.69 & 7.80 \\
\hline 99/011 & 46.53 & 62.94 & 85.11 & 1.08 & 1.67 & 5.80 & 7.09 & 7.55 \\
\hline 99/012 & 54.80 & 60.47 & 100.90 & 1.15 & 1.70 & 5.50 & 5.42 & 7.09 \\
\hline $82 / 414$ & 48.80 & 69.66 & 102.80 & 1.26 & 1.72 & 6.45 & 5.55 & 7.53 \\
\hline $82 / 125$ & 43.87 & 66.97 & 88.96 & 0.76 & 1.64 & 5.98 & 6.19 & 7.70 \\
\hline $87 / 160$ & 58.08 & 59.33 & 103.30 & 1.17 & 1.74 & 6.16 & 6.62 & 7.98 \\
\hline $87 / 134$ & 73.20 & 32.10 & 60.76 & 0.81 & 1.00 & 5.35 & 4.11 & 6.97 \\
\hline $82 / 166$ & 59.73 & 70.19 & 126.10 & 1.15 & 1.77 & 5.80 & 6.87 & 7.89 \\
\hline $87 / 118$ & 42.87 & 67.53 & 85.23 & 1.17 & 1.74 & 5.80 & 6.13 & 7.29 \\
\hline 99/013 & 87.00 & 31.53 & 80.50 & 0.74 & 1.13 & 5.65 & 6.17 & 7.78 \\
\hline $82 / 482$ & 40.34 & 59.77 & 71.90 & 1.07 & 1.64 & 5.80 & 5.85 & 7.48 \\
\hline $82 / 493$ & 50.87 & 63.40 & 94.50 & 1.11 & 1.68 & 5.35 & 6.01 & 7.22 \\
\hline $82 / 469$ & 67.73 & 23.90 & 87.48 & 0.73 & 0.90 & 5.65 & 5.25 & 6.47 \\
\hline $82 / 489$ & 56.60 & 54.84 & 88.70 & 1.07 & 1.57 & 5.35 & 6.73 & 8.78 \\
\hline $99 / 014$ & 46.33 & 55.83 & 76.60 & 1.08 & 1.62 & 5.50 & 5.79 & 6.59 \\
\hline $99 / 015$ & 51.33 & 71.81 & 109.30 & 1.16 & 1.70 & 5.95 & 6.89 & 9.21 \\
\hline 99/017 & 45.87 & 57.81 & 81.00 & 1.15 & 1.73 & 5.65 & 6.21 & 7.40 \\
\hline 99/018 & 46.08 & 61.83 & 86.40 & 1.09 & 1.70 & 7.18 & 6.31 & 7.31 \\
\hline $82 / 496$ & 51.47 & 54.01 & 80.46 & 1.15 & 1.65 & 5.35 & 5.49 & 6.87 \\
\hline $82 / 505$ & 63.27 & 57.51 & 144.40 & 1.07 & 1.66 & 5.20 & 4.89 & 6.63 \\
\hline $\mathrm{CV}(\%)$ & 20.94 & 31.12 & 28.40 & 18.60 & 21.92 & 11.76 & 17.74 & 12.05 \\
\hline LSD $(5 \%$ & 4.91 & 0.79 & 7.08 & 0.05 & 0.02 & 0.17 & 0.10 & \\
\hline
\end{tabular}

Loi (1994) and Esquivel et al. (1990) identified five different morphotypes of Lima based on seed weight, seed length and seed weight as follows: Big Lima (100-110 g, $25 \mathrm{~mm}$ long, $14 \mathrm{~mm}$ wide), Sieva (30-45.3 g, $12 \mathrm{~mm}$ long), Potato ( $35.5 \mathrm{~g}, 9 \mathrm{~mm}$ long, $8 \mathrm{~mm}$ wide), Potato-Sieva (36.3 g, $11 \mathrm{~mm}$ long, $8 \mathrm{~mm}$ wide) and Sieva-Big (77.5 g, $17 \mathrm{~mm}$ long, $11 \mathrm{~mm}$ wide). Based on these criteria, the 31 accessions of the present work could be representatives of the Potato, PotatoSieva and Sieva-Big morphotypes of Loi (1994) and Esquivel et al. (1990). To confirm the absence of the Big Lima type in Ghana large number of accessions must be collected and subjected to further analysis. The use of seed morphotype for classification must be used with caution because seed weight, seed length and seed width can be influenced by the environment and also the level of heritability of these characters must be determined.

TABLE 2

Summary description of band pattern in 31 Lima bean accessions

$\begin{array}{cccc}\text { Band } & \text { Relative distance } & \text { Total number of bands } & \text { Band frequency } \\ 1 & 0.01 & 1 & 0.003\end{array}$

West African Journal of Applied Ecology, Vol. 12, 2008 


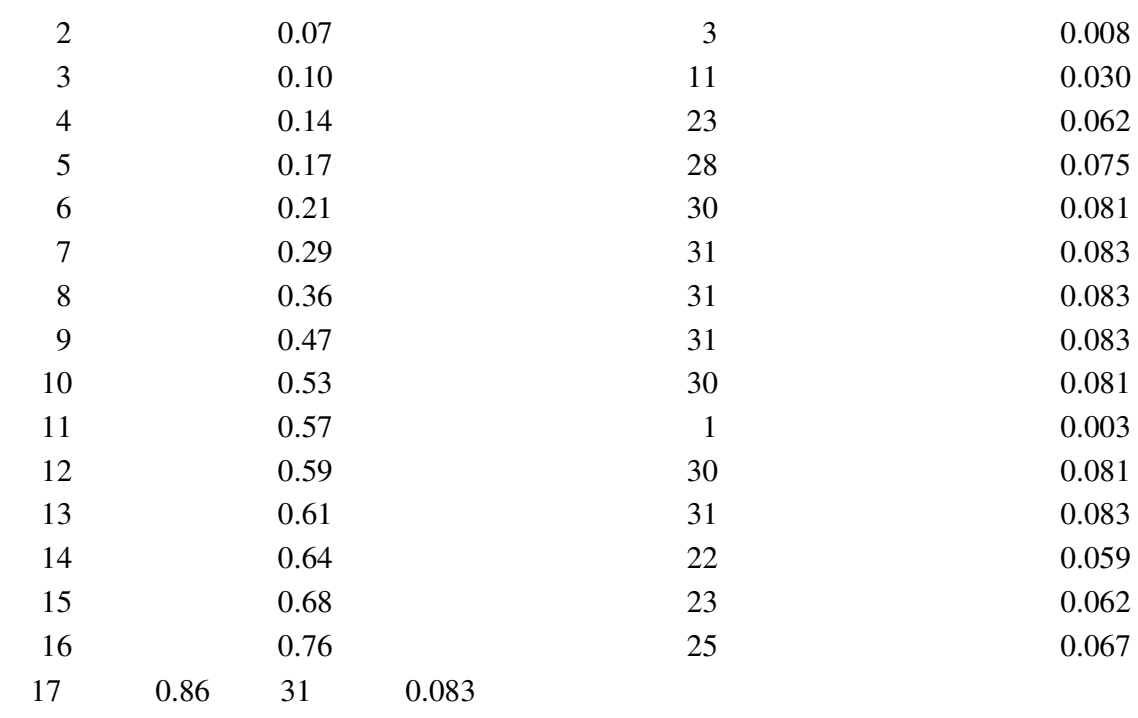

Association between seed coat colour and seed characteristics, pod beak length and seed characteristics

An ordinal logistic regression analysis was performed to test for association between the quantitative and qualitative characters. The following characters were found to have effect on seed coat colour: seed weight (constant $=-0.091, \mathrm{z}=-3.34, \mathrm{P}=0.001$, odd ratio $=0.91$ ), seed width (constant $=-6.145, \mathrm{z}=-2.83, \mathrm{P}=0.005$, odd ratio $=0.00)$ and seed length (constant $=-$ 4.161, $\mathrm{z}=-3.21, \mathrm{P}=0.001$, odd ratio $=0.02$ ) in the same manner seed weight (constant $=0.999, \mathrm{z}$ $=3.24, \mathrm{P}=0.001$, odd ratio $=1.10$ ), seed length (constant $=4.588, \mathrm{z}=3.11, \mathrm{P}=0.002$, odd ratio $=98.28)$, and seed width $($ constant $=5.604, \mathrm{z}=2.54, \mathrm{P}=0.011$, odd ratio $=271.49)$ showed effect on pod beak shape.

Association among characters could be attributed to either genetic linkage or pleiotropy. Sax (1923) found linkage between seed colour and seed size in segregating population of Phaseolus vulgaris. Brittingham (1950) reported association between genes controlling buff seed-coat and pod length, the genes controlling general colour factor and seed size in the Vigna unguiculata, Saunders (1960) also suggested that seed-coat colour and date of maturity are associated in a quantitative-qualitative linkage in the same species.

In the present study there was evidence between a quantitative-qualitative association for seed coat, pod beak shape (qualitative), and seed weight, seed length and seed width (quantitative). This association could be attributed to either genetic linkage or pleiotropy. Further study is underway to develop mapping populations to confirm this finding. It, therefore, remains to comment that in addition to seed morphotypes as the main basis of Lima classification, polymorphisms in seed coat colour and pod beak shape observed in the present work can be used as criteria for further classification in Lima bean. This association can also give an evidence of coevolution of seed coat colour, pod beak shape and seed size in the Lima bean.

\section{Seed protein}

Seed protein analysis of the Lima bean accessions studied revealed the presence of 17 bands. Table 3 shows a summary description of band pattern. Relative mobility of bands ranged from 0.01 to 0.86 . Bands 7, 8, 9, 13 and 17 were present in all 31 accessions, while bands 1 and 11 were present in only accessions 87/166 and 82/144, respectively. Band 2 was present in accessions 82/134, 99/013 and 82/414. Bands 1 and 11 recorded the lowest frequency of 0.003 each (Table 3).

\section{TABLE 3}

West African Journal of Applied Ecology, Vol. 12, 2008 
Mean of relevant characteristics for each of the six clusters

\begin{tabular}{|c|c|c|c|c|c|c|}
\hline \multirow[t]{2}{*}{ Characteristic } & \multicolumn{6}{|c|}{ Cluster } \\
\hline & 1 & 2 & 3 & 4 & 5 & 6 \\
\hline No. of seeds per pod & 52.10 & 48.80 & 63.40 & 44.07 & 57.27 & 73.22 \\
\hline 100-seed weight $(\mathrm{g})$ & 68.92 & 69.66 & 40.04 & 23.84 & 29.45 & 28.72 \\
\hline Grain yield $(\mathrm{g})$ & 98.36 & 102.8 & 71.65 & 31.78 & 49.57 & 66.82 \\
\hline Seed width $(\mathrm{cm})$ & 1.11 & 1.26 & 0.96 & 0.62 & 0.74 & 0.76 \\
\hline Seed length $(\mathrm{cm})$ & 1.69 & 1.72 & 1.35 & 0.86 & 0.97 & 1.00 \\
\hline $\mathrm{HCN}(\mathrm{mg} / 100 \mathrm{~g})$ & 5.79 & 6.45 & 7.00 & 7.10 & 7.85 & 5.54 \\
\hline Terminal leaflet length $(\mathrm{cm})$ & 6.29 & 5.55 & 7.24 & 4.94 & 2.44 & 5.04 \\
\hline Terminal leaflet width $(\mathrm{cm})$ & 7.74 & 7.53 & 9.30 & 6.78 & 10.58 & 7.36 \\
\hline
\end{tabular}

\section{Phenetic analysis}

UPGMA cluster analysis of phenotypic (quantitative and qualitative) data based on Gower General Similarity Coefficient grouped the accessions into six major clusters at 0.76 similarity level (Fig. 1). The first cluster comprised 20 accessions. The second cluster contained only one accession (Accession 82/414) and the third cluster contained two accessions (Accessions 99/002 and 99/004). The fourth and fifth clusters contained one accession each. Means of the eight quantitative characters associated with each cluster are presented in Table 4 . The sixth cluster was associated with the highest mean number of seeds per pod (73.22), while the fourth cluster was associated with the lowest number of seeds per pod. The fourth cluster had the lowest mean 100seed weight $(23.84 \mathrm{~g})$. The second cluster gave the highest mean grain yield $(102.8 \mathrm{~g})$, while the fourth cluster was associated with the lowest mean grain yield $(31.73 \mathrm{~g})$. The highest mean seed width $(1.26 \mathrm{~mm})$ was associated with the second cluster, while the lowest mean seed width $(0.62$ $\mathrm{mm})$ was associated with the fourth cluster. The highest mean terminal leaflet length $(7.24 \mathrm{~cm})$ was associated with the third cluster, while the lowest mean terminal leaflet length $(2.44 \mathrm{~cm})$ was associated with the fifth cluster. 


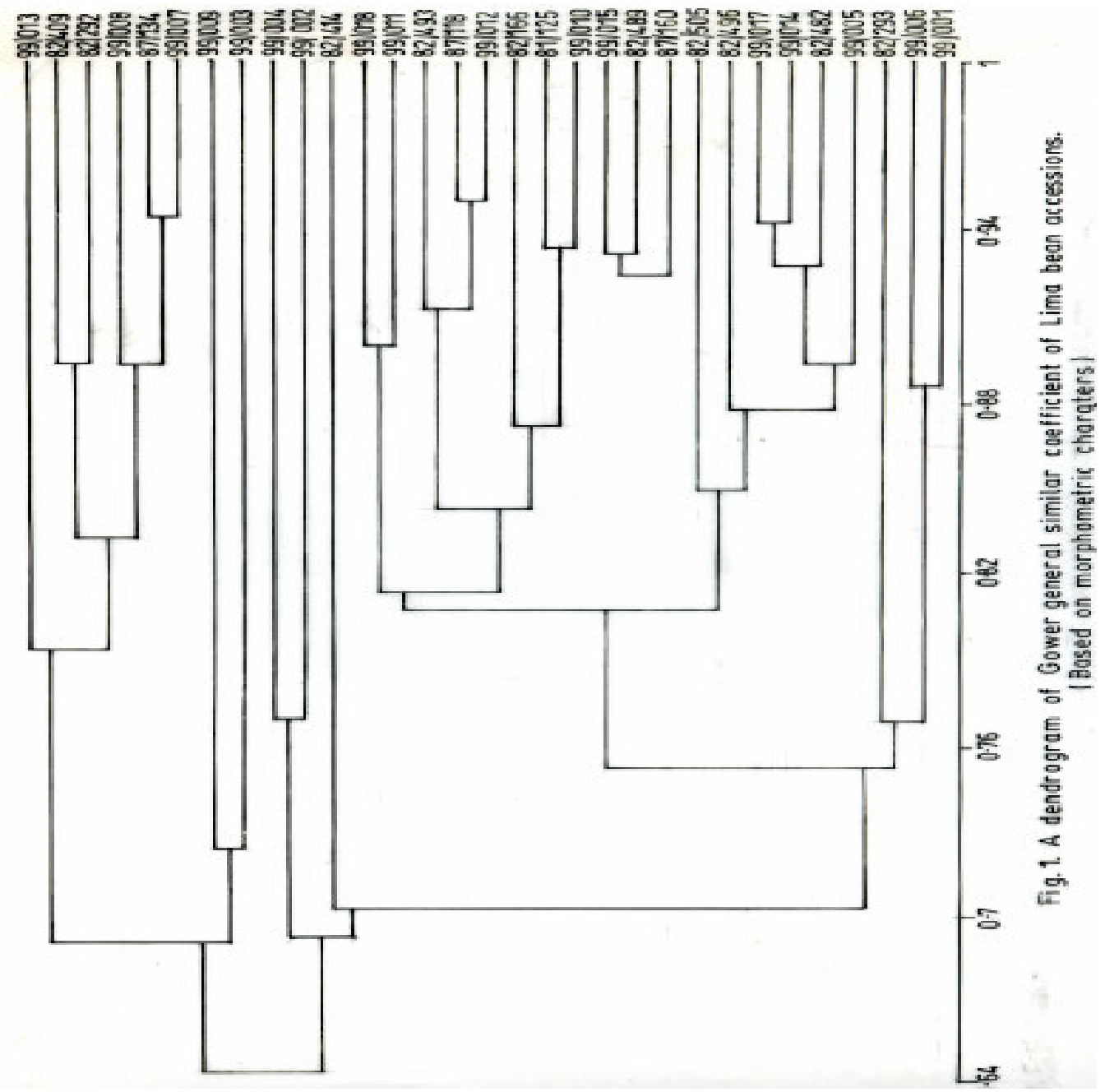

TABLE 4

Qualitative characteristics of 31 accessions of lima accessions

\begin{tabular}{|c|c|c|c|c|c|}
\hline Accession & $\begin{array}{l}\text { Wing } \\
\text { opening }\end{array}$ & $\begin{array}{l}\text { Pod raceme } \\
\text { position }\end{array}$ & $\begin{array}{l}\text { Pod dehiscence } \\
\text { (initial) }\end{array}$ & $\begin{array}{l}\text { Pod raceme } \\
\text { position at } 90 \% \\
\text { full pod }\end{array}$ & $\begin{array}{l}\text { Persistence } \\
\text { of leaf }\end{array}$ \\
\hline $99 / 001$ & Parallel & Within foliage & Non shattering & Within foliage & Intermediate \\
\hline $99 / 002$ & Parallel & Intermediate & Non shattering & Intermediate & Intermediate \\
\hline $99 / 003$ & Parallel & Within foliage & Non shattering & Intermediate & Intermediate \\
\hline $99 / 004$ & Parallel & Intermediate & Non shattering & Within foliage & Few leaves remaining \\
\hline $99 / 005$ & Parallel & Within foliage & Non shattering & $\begin{array}{l}\text { Emerging from } \\
\text { leaf canopy }\end{array}$ & Intermediate \\
\hline 99/006 & Parallel & Intermediate & Non shattering & Within foliage & Intermediate \\
\hline 99/007 & Parallel & $\begin{array}{l}\text { Emerging from } \\
\text { leaf canopy }\end{array}$ & $\begin{array}{l}\text { Dehisce no } \\
\text { shattering }\end{array}$ & $\begin{array}{l}\text { Emerging from } \\
\text { leaf canopy }\end{array}$ & Few leaves remaining \\
\hline $99 / 008$ & Parallel & $\begin{array}{l}\text { Emerging from } \\
\text { leaf canopy }\end{array}$ & Non shattering & $\begin{array}{l}\text { Emerging from } \\
\text { leaf canopy }\end{array}$ & Few leaves remaining \\
\hline $82 / 293$ & Intermediate & Intermediate & Non shattering & Within foliage & Few leaves remaining \\
\hline $82 / 292$ & Parallel & Intermediate & Non shattering & Intermediate & Intermediate \\
\hline $99 / 009$ & Parallel & Within foliage & Non shattering & Emerging from & Intermediate \\
\hline
\end{tabular}

West African Journal of Applied Ecology, Vol. 12, 2008 


\begin{tabular}{|c|c|c|c|c|c|}
\hline \multirow[b]{2}{*}{$99 / 010$} & \multirow[b]{2}{*}{ Parallel } & \multirow[b]{2}{*}{ Intermediate } & \multicolumn{2}{|r|}{ leaf canopy } & \multirow[b]{2}{*}{ Intermediate } \\
\hline & & & Non shattering & Intermediate & \\
\hline 99/011 & Intermediate & Intermediate & Non shattering & Intermediate & Intermediate \\
\hline 99/012 & Parallel & Intermediate & Non shattering & Intermediate & Few leaves remaining \\
\hline $82 / 414$ & Parallel & Within foliage & Non shattering & Within foliage & Few leaves remaining \\
\hline \multicolumn{6}{|l|}{$82 / 125$} \\
\hline $87 / 160$ & Parallel & Within foliage & Non shattering & Within foliage & Few leaves remaining \\
\hline $87 / 134$ & Parallel & $\begin{array}{l}\text { Emerging from } \\
\text { leaf canopy }\end{array}$ & Non shattering & $\begin{array}{l}\text { Emerging from } \\
\text { leaf canopy }\end{array}$ & Few leaves remaining \\
\hline $82 / 166$ & Parallel & Intermediate & Non shattering & Within foliage & Intermediate \\
\hline $87 / 118$ & Parallel & Intermediate & Non shattering & Intermediate & Few leaves Remaining \\
\hline 99/013 & Parallel & $\begin{array}{l}\text { Emerging from } \\
\text { leaf canopy }\end{array}$ & $\begin{array}{l}\text { Dehisce non } \\
\text { shattering }\end{array}$ & $\begin{array}{l}\text { Emerging from } \\
\text { leaf canopy }\end{array}$ & Intermediate \\
\hline $82 / 482$ & Parallel & Within foliage & Non shattering & Intermediate & Intermediate \\
\hline $82 / 493$ & Parallel & Intermediate & Non shattering & Intermediate & Intermediate \\
\hline $82 / 469$ & Parallel & Intermediate & Non shattering & Intermediate & Few leaves remaining \\
\hline $82 / 489$ & Intermediate & Within foliage & Non shattering & Within foliage & Few leaves remaining \\
\hline 99/014 & Parallel & Within foliage & Non shattering & Within foliage & Intermediate \\
\hline 99/015 & Parallel & Within foliage & Non shattering & Within foliage & Few leaves remaining \\
\hline 99/017 & Parallel & Within foliage & Non shattering & Within foliage & Intermediate \\
\hline 99/018 & Intermediate & Within foliage & Non shattering & Within foliage & Intermediate \\
\hline $82 / 496$ & Parallel & Within foliage & Non shattering & Intermediate & Intermediate \\
\hline \multirow[t]{2}{*}{$82 / 505$} & Parallel & Within foliage & Non shattering & Intermediate & Intermediate \\
\hline & \multicolumn{5}{|c|}{ Table 4 cont'd } \\
\hline Accession & $\begin{array}{l}\text { Seed testa } \\
\text { colour }\end{array}$ & Beak shape & $\begin{array}{l}\text { Flower wing } \\
\text { colour }\end{array}$ & Colour of keel & Hairiness of standard \\
\hline 99/001 & brown & Long & Light pink & Pink & Sparsely on tip \\
\hline 99/002 & cream & Short & Light pink & Pink & Moderate \\
\hline $99 / 003$ & cream & Short & Violet & Pink & Sparsely on tip \\
\hline 99/004 & purple brown & Medium & Light pink & Pink & Sparsely on tip \\
\hline 99/005 & white & Medium & White & Green & Sparsely on tip \\
\hline 99/006 & brown & Medium & Light pink & Pink & Sparsely on tip \\
\hline 99/007 & brown & Long & White & Green & Sparsely on tip \\
\hline 99/008 & purple red & Short & White & Green & Sparsely on tip \\
\hline $82 / 293$ & white & Long & White & Green & Sparsely on tip \\
\hline $82 / 292$ & cream & Short & White & Green & Sparsely on tip \\
\hline 99/009 & brown & Short & White & Green & Moderate \\
\hline 99/010 & white & Medium & White & Green & Sparsely on tip \\
\hline 99/011 & white & Medium & White & Green & Sparsely on tip \\
\hline 99/012 & white & Medium & White & Green & Sparsely on tip \\
\hline $82 / 414$ & purple brown & Long & Light pink & Pink & Moderate \\
\hline $82 / 125$ & white & Long & White & Green & Sparsely on tip \\
\hline $87 / 160$ & white & Short & White & Green & Sparsely on tip \\
\hline $87 / 134$ & purple red & Short & White & Green & Sparsely on tip \\
\hline $82 / 166$ & white & Medium & White & Green & Sparsely on tip \\
\hline $87 / 118$ & white & Medium & White & Green & Sparsely on tip \\
\hline 99/013 & cream & Medium & White & Green & Sparsely on tip \\
\hline
\end{tabular}




\begin{tabular}{|c|c|c|c|c|c|}
\hline $82 / 482$ & white & Medium & White & Green & Sparsely on tip \\
\hline $82 / 493$ & white & Medium & White & Green & Moderate \\
\hline $82 / 469$ & cream & Short & White & Green & Sparsely on tip \\
\hline $82 / 489$ & white & Medium & White & Green & Sparsely on tip \\
\hline $99 / 014$ & white & Long & White & Green & Sparsely on tip \\
\hline $99 / 015$ & white & Medium & White & Green & Sparsely on tip \\
\hline $99 / 017$ & white & Medium & White & Green & Sparsely on tip \\
\hline $99 / 018$ & white & Medium & White & Green & Sparsely on tip \\
\hline $82 / 496$ & white & Medium & White & Green & Moderate \\
\hline $82 / 505$ & white & Medium & White & Green & Sparsely on tip \\
\hline
\end{tabular}

UPGMA cluster analysis of the protein profile based on Jaccard's index grouped the accessions into three major clusters at 0.76 level of similarity (Fig. 2). The first cluster contained 29 accessions. Within the first cluster there were four sub-clusters of which the first, second, third and fourth sub-clusters contained seven, 10, six and six accessions, respectively. The second and third major clusters comprised one accession each, namely accession 82/293 and 99/007, respectively. Eighty-five per cent of the accessions in the first cluster of the morphological data formed about $62 \%$ of the accessions in the first cluster of the protein data. 


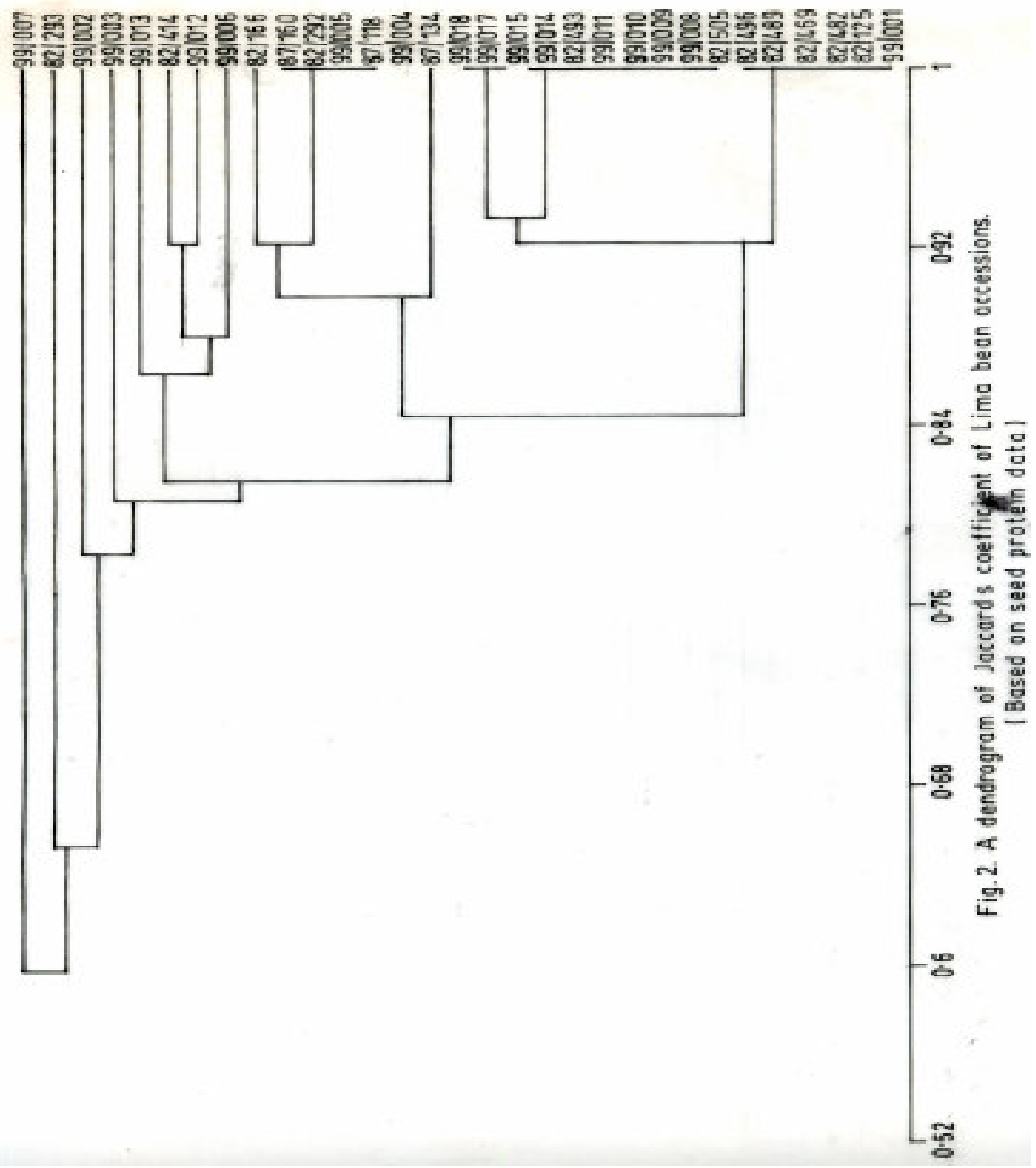

Accessions 82/293 and 99/007 in clusters 1 and 2 of the morphological data clustered into two separate clusters based on the protein data. The present study gives evidence of morphological and protein variation among the Lima bean accessions studied. The study also showed intervarietal variations within the accessions by the use of total seed protein data. The electrophoretic descriptors of the seed proteins can be used as effective technique in genebanks involved in Lima bean identification and differentiation. The differences observed among the accessions available in Ghana would be of immediate importance for broadening the Lima bean genepool and may be used in hybridization and breeding programmes.

\section{Acknowledgement}

The authors are most grateful to the PGRC of the CSIR for providing us with the Lima bean seeds. They are also thankful to Mr Augustine Tonyigah, Chief Technician of the Department of Crop Science, University of Ghana, and his technical team, for the seed protein electrophoresis experiment.

\section{References}

Badr A. (1995). Electrophoretic studies of seed proteins relation to chromosomal criteria and relationships of some taxa of Trifolium. Taxon 44: 183-191.

Baudoin J. P., Barthelemy J. P and Ndungo V. (1991). Variability of cyanide contents in the primary and secondary genepools of lima bean (Phaseolus lunatus). Pl. Genet. Resour. Newsl. 85: 5-9.

West African Journal of Applied Ecology, Vol. 12, 2008 
Brittingham W. H. (1950). The inheritance of date of pod maturity, pod length, seed shape and seed size in the southern pea, Vigna sinensis. Proc. Am. Soc. Hort. Sci. 51: 281-288.

Doku E. V. (1977). Grain legume production in Ghana. In Proceedings of the Joint University of Ghana Council for Scientific and Industrial Research Symposium on Grain Legumes in Ghana. (E. V. Doku, ed.), pp. 1-7. The Institute of Adult Education, University of Ghana.

Esquivel M, Castineiras L. and Hammer K. (1990). Origin, classification, variation and distribution of lima bean (Phaseolus lunatus L.) in the light of Cuban material. Euphytica 49: 89-97.

FAO (1984). Legumes inoculates and their use. Food and Agriculture Organization of the United Nations, Rome.

FAO/CCTA (1958). Report of the FAO/CCTA technical meeting on legumes in agriculture and human nutrition in Africa. FAO, Rome.

Gardiner S. E. and Forbe M. B. (1992). Identification of cultivars of grasses and forage legumes by SDS-PAGE of seed protein. In Seed analysis. (H. F. Linskens and J. F. Jackson, ed.), pp. 43-61. Springer-Verlag, Berlin, New York.

Gepts P. (1990). Genetic diversity of seed storage proteins in plants. In Plant populations genetics, breeding and genetic resources. (A. H. D. Brown, M.T. Clegg, A. L. Khaler and B. S. Weir, ed.), pp. 64-82. Sinauer Associates Inc., Sunderland, Massachusetts.

Gepts P., Osborn T. C., Rashka K. and Bliss F. A. (1986). Phaseolin-protein variability in wild form and landraces of the common bean (Phaseolus vulgaris); evidence for multiple centres of domestication. Econ. Bot. 40: 451-468.

Loi L. (1994). Morphotype relationships in Lima bean (Phaseolus lunatus L.) deduced from variation of the evolutionary marker phaseolin. Genet. Resour. Crop Evol. 41: 81-85.

Odeigah P. G. C., Oboh B. and Aghalope I. O. (1999). The characterization of Nigerian varieties of pepper, $C$. annuum and $C$. frutescens by SDS polyacrylamide gel electrophoresis of seed protein. Genet. Resour. Crop Evol. 46: $127-131$.

Sanchez-Yelamo M. D, Espenjo-Ibanez M. C., Francisco-Ortega J. and Santose-Guerra A.(1995). Electrophoretical evidence of variation in populations of the fodder legume Chmaecytisus proliferus from the Canary Islands. Biochem. Syst. Eco. 23: 53-63.

Saunders A. R (1960). Inheritance in the cowpea (Vigna sinensis Endb.) 3. Mutations and linkages. S. Afr. J. agric. Sci. 3: 327-348.

Sax K (1923). The association of size differences with seed-coat pattern and pigmentation in Phaseolus vulgaris. Genetica 8: 552-560.

Sheidai M., Hamta A., Jaffari A. and Noori-Daloli M. R. (2000). Morphometric and seed protein studies of Trifolium species and cultivars in Iran. Pl. Genet. Resour. Newsl. 120: 52-54.

West African Journal of Applied Ecology, Vol. 12, 2008 